Vlatka Lemić, Koraljka Kuzman Šlogar: Tematski portali Znameniti.hr i EminentPeople.eu - izazovi i perspektive virtualnoga umrežavanja digitalnih repozitorija

\title{
Tematski portali Znameniti.hr i EminentPeople.eu - izazovi i perspektive virtualnoga umrežavanja digitalnih repozitorija
}

\author{
Vlatka Lemić \\ Sveučilište u Zagrebu \\ vlatka.lemic@unizg.hr \\ Koraljka Kuzman Šlogar \\ Institut za etnologiju i folkloristiku, Zagreb \\ koraljka@ief.hr
}

SAŽETAK: Kulturnom i znanstvenom sektoru informacijsko je doba donijelo nove izazove, ali i nove mogućnosti, kako za razvoj tako i za prezentaciju svojih primarnih djelatnosti, zahvaljujući brojnim inovativnim tehnologijama i metodama. Još važnije, otvorilo im je nove mogućnosti umrežavanja putem međuinstitucionalnih i multidisciplinarnih suradničkih projekata, temeljenih na povezivanju istovrsnih potreba, napora i ideja. Cilj je ovoga rada predstaviti i problematizirati mogućnosti suradnje u virtualnom okruženju između srodnih ustanova, okupljenih oko zajedničkoga projekta razvoja suradničkoga portala tematski vezanoga uz znamenite i zaslužne osobe. Projekt ćemo predstaviti kroz njegove tri temeljne razvojne faze: od samoga začetka ideje i pokretanja nacionalnoga pilot-projekta Znameniti $i$ zaslužni Hrvati koji je rezultirao stvaranjem portala Znameniti.hr, preko jednogodišnjega europskog projekta koji je financirao konzorcij DARIAH-ERIC, omogućivši uspostavu regionalne suradnje i kreiranja portala na domeni EminentPeople.eu, do pripreme novoga međunarodnog projekta kroz razmatranja europske perspektive ovoga portala.

Ključne riječi: suradnički portal; institucijska suradnja; digitalni repozitorij; digitalizacija; znamenite osobe; kulturno $i$ znanstveno nasljeđe

\section{Uvod}

Digitalno je doba kulturnom i znanstvenom sektoru donijelo brojne izazove, ali i nove perspektive razvoja i prezentacije svojih primarnih djelatnosti, ponajviše zahvaljujući mogućnostima inovativnih tehnologija. Možda još važnije: otvorilo im je nove mogućnosti umrežavanja i suradnje kroz različite multidisciplinarne i međuinstitucionalne projekte i programe, koji se temelje na istovrsnim potrebama, ciljevima i idejama u različitim stručnim područjima. Suvremeni trendovi baštinsku i akademsku zajednicu usmjeravaju na suradnju s drugim strukama, stvarateljima zapisa 
i korisnicima u stvaranju zajedničke informacijske infrastrukture i kulturnih sadržaja, pri čemu je digitalizacija odigrala presudnu ulogu u javnom predstavljanju kulturne baštine te povijesnih i dokumentarnih izvora kroz raznovrsne tematske $\mathrm{i}$ institucionalne portale, baze podataka, digitalne platforme, virtualne zbirke, multimedijske sadržaje i razne informacijske servise.

U radu će se predstaviti i problematizirati upravo jedan takav primjer suradnje srodnih baštinskih i znanstvenih institucija u digitalnom okruženju koje je okupio projekt stvaranja portala Znameniti.hr, tematski vezan uz poznate i zaslužne osobe iz znanosti, kulture i javnoga života. Projekt je do ovoga trenutka prošao kroz prve dvije, od tri zamišljene faze razvoja, implementacije i korištenja. U tekstu što slijedi donosi se pregled dosadašnjih suradničkih aktivnosti, od začetka ideje i pokretanja nacionalnoga pilot-projekta Znameniti i zaslužni Hrvati koji je rezultirao stvaranjem portala Znameniti.hr, preko jednogodišnjega europskog projekta financiranoga od strane europskoga konzorcija Digital Research Infrastructure for Arts and Humanities - European Research Infrastructure Consortium ${ }^{1}$ (dalje u tekstu DARIAH-ERIC) koji je pružio okvir za uspostavu regionalne suradnje i kreiranja novoga portala EminentPeople.eu, do razmatranja buduće europske perspektive portala kroz pokretanje novoga međunarodnog projekta. Paralelno s ovim aktivnostima suradnici na portalu radili su i na drugim, specifičnim i manje opsežnim projektima koji su implementirani u svrhu kontinuiranoga razvoja i održavanja portala te razvoja publike i javnoga predstavljanja aktivnosti i sadržaja na portalu.

\section{Digitalizacija kulturne baštine u Hrvatskoj}

Prateći europske inicijative razvoja informacijskoga društva, u Hrvatskoj je početkom XXI. stoljeća doneseno više nacionalnih strategija, inicijativa i programa u okviru kojih je potaknuta, planirana i provodi se digitalizacija kulturne baštine. $U$ strategiji Informacijska i komunikacijska tehnologija - Hrvatska u 21. stoljeću ${ }^{2}$, donesenoj 2002. godine, na nacionalnoj je razini postavljen institucionalni okvir za poticanje razvoja informacijske i komunikacijske tehnologije kao preduvjeta za jednostavan pristup, prijenos i upotrebu informacija i znanja. Za postizanje toga cilja bile su planirane dugoročne aktivnosti, posebno one vezane uz obrazovanje, a najveći troškovi bili su predviđeni za opremanje obrazovnih, znanstvenih, kulturnih i zdrav-

1 U prijevodu: Digitalna istraživačka infrastruktura za umjetnost i humanističke znanosti Konzorcij europskih istraživačkih infrastruktura. Ovaj je konzorcij zamišljen kao vodeća europska organizacija za digitalna istraživanja na području umjetnosti i humanistike, a čini ga »mreža ljudi, ekspertiza, informacija, znanja, sadržaja, metoda, alata i tehnologija« (ESFRI Roadmap 2016: 83; za više informacija vidi npr. Kuzman Šlogar 2017).

2 NN 109/2002, dostupno na: http://narodne-novine.nn.hr/clanci/sluzbeni/2002_09_109_1753.html 
stvenih institucija, izgradnju elektroničke uprave i javnih službi te digitalizaciju kulturnih, nacionalnih, obrazovnih, zdravstvenih i poslovnih sadržaja.

Početci digitalizacije u sektoru kulture mogu se pratiti od 1990-ih godina, a posljednjih desetljeća digitalizacija je postala sastavni dio nacionalnih kulturnih politika i programa, kao i planova i aktivnosti kulturnih ustanova. Ministarstvo kulture je potencijale informacijskih tehnologija u kulturi u digitalnom dobu na području zaštite i dostupnosti 2005. godine počelo oblikovati u Nacionalni program digitalizacije arhivske, knjižnične i muzejske građe (Nacionalni projekt Hrvatska kulturna baština), obuhvativši pojmom digitalizacije obradu, tehnički postupak digitalizacije, online dostupnost, upravljanje pravima i dugoročnu zaštitu (Lemić 2017: 98).

Važnost digitalizacije građe kulturnih ustanova naglašena je kroz nekoliko aspekata: digitalno okruženje kao prostor izražavanja, komunikacije, stjecanja i razmjene iskustava, stavova i vrijednosti; dostupnost građe; sposobnost za umrežavanje; stvaranje novih usluga i zaštita. Na temelju donesenoga nacionalnog programa digitalizacije u razdoblju od 2007. do 2009. godine pokrenut je pilot-projekt digitalizacije Hrvatska kulturna baština s ciljem stvaranja potrebnih tehničkih, infrastrukturnih i kadrovskih uvjeta te poticajne klime za pokretanje i izvršavanje takvih projekata u Hrvatskoj, u kojemu je pod vodstvom Ministarstva surađivalo više kulturnih ustanova, IT tvrtke i brojni stručnjaci i suradnici. Od projektom predviđenih aktivnosti 2008. godine realiziran je kooperativni nacionalni portal Hrvatska kulturna baština, koji danas više nije u funkciji, ${ }^{3}$ dok drugi planirani programi (izrada specifikacije modela digitalne zbirke, Centar za podršku i praćenje projekata digitalizacije, kooperativni digitalni arhiv/s odgovarajućim hardverskim, softverskim i kadrovskim rješenjem/ te edukacija i izgradnja infrastrukture) nisu praktično zaživjeli.

Nakon prve faze projekta, Vijeće projekta je za razdoblje od 2010. do 2011. godine donijelo novi plan aktivnosti koji je uključivao daljnji rad na provedbi Nacionalnoga programa digitalizacije arhivske, knjižnične i muzejske građe i na portalu Hrvatska kulturna baština, stvaranje liste prioriteta ugrožene i često korištene građe, poticanje digitalizacije i suradničkih projekata, izradu smjernica za digitalizaciju posebnih vrsta građe, nastavak edukacije i pripremu podataka za integraciju u Europeanu. U narednom razdoblju između 2012. i 2015. godine Vijeće projekta je zajedno s radnim skupinama za izradu Strategije digitalizacije kulturne baštine do 2020. radilo na izradi nove nacionalne strategije, usmjerene prema dvama ciljevima:

- $\quad$ konsolidiranje i jačanje infrastrukture za digitalizaciju, korištenje i očuvanje digitalne kulturne baštine

3 Stranica portala i dalje postoji u svojoj prvotnoj verziji na www.kultura.hr, no neaktivna je i ne ažurira se već dulji niz godina. 
- stvaranje konkurentskoga položaja na europskom tržištu čija se ostvarenja temelje na infrastrukturi, digitalnim sadržajima, interoperabilnosti, e-uslugama i konkurentnosti (Lemić 2017: 98-99).

Ova strategija, kojom je bilo predviđeno definiranje infrastrukturnoga nacionalnog sustava kojim bi se hrvatska kulturna baština uključila u međunarodne kulturne portale kao dio europske kulturne baštine, nije zaživjela, no sredinom 2019. godine javnosti je kroz e-savjetovanje predstavljen Nacionalni plan digitalizacije kulturne baštine 2025, koji se temelji na pet ključnih postavki bitnih za ostvarenje zacrtanih ciljeva: infrastruktura, digitalni sadržaj, interoperabilnost, e-usluge i održivost. U njemu su digitalizirani kulturni sadržaji istaknuti kao važan resurs europske kulture i kreativne industrije. Sam se plan nadovezuje na projekt Hrvatska kulturna baština (2007-2012), Zaključke Europskoga vijeća o digitalizaciji i online dostupnosti kulturnoga sadržaja i digitalnoj zaštiti (2012-2015), Strategiju Europa 2020 i Strategiju eHrvatska 2020 (Nacionalni plan digitalizacije kulturne baštine 2025: 2-3). Uz iscrpne analize stanja, ovim su planom postavljena dva strateška cilja:

- unapređenje mrežne dostupnosti digitalne kulturne baštine

- osiguravanje održivosti umreženoga središnjeg sustava za digitalnu kulturnu baštinu (Nacionalni plan digitalizacije kulturne baštine 2025: 11).

Kao prioriteti za unapređenje mrežne dostupnosti digitalne kulturne baštine istaknuti su uspostava umreženoga središnjeg sustava za digitalnu kulturnu baštinu te osiguranje i poticanje njezina korištenja. Prioriteti vezani uz osiguravanje održivosti umreženoga središnjeg sustava za digitalnu kulturnu baštinu uključuju kontinuirano praćenje, vrednovanje i izvještavanje o rezultatima Plana te razvoj novih proizvoda i usluga (ibid.).

Iz navedenih je planova i strategija razvidno da je u Hrvatskoj odavno prepoznata potreba suradnje između javnih ustanova na digitalizaciji i razvoju digitalnih infrastruktura, te se cijelo to vrijeme radi ponešto i na pokušajima njezina ostvarenja. Stručne zajednice arhivista, knjižničara i muzealaca 1997. godine započele su organizaciju godišnjih seminara Arhivi, knjižnice, muzeji: mogućnosti suradnje u okruženju globalne informacijske infrastrukture (vidi Wiler 2019). Prateći njihove programe, izvješća vezana uz pojedine kulturne strategije i djelatnosti te aktivnosti pojedinih ustanova, razvidno je da se relativno uspješno ostvaruju manje zahtjevne suradnje, primjerice one dogovorene između dviju ustanova koje prepoznaju zajednički interes i u kojima sami projekti ne zahtijevaju veća sredstva, dok sama »digitalna infrastruktura u Hrvatskoj još uvijek čeka snažniji investicijski ciklus« (Crnković i sur. 2017: 181). Veći dio stručnjaka koji se bave ovim područjem mišljenja je da je za izgradnju složene i zahtjevne digitalne infrastrukture kakvu trebaju humani- 
stičke i društvene znanosti i AKM (arhivi-knjižnice-muzeji) zajednica potrebna standardizacija i bolja suradnja svih uključenih dionika, kao i veća povezanost i transparentnost za međusobnu razmjenu informacija (Crnković i sur. 2017: 181; Lemić 2017: 114).

Jedna od prvih suradnji u području razvoja digitalne infrastrukture bila je ideja o pilot-projektu izrade modela hrvatske digitalne knjižnice koja je okupila više knjižnica. Koordinaciju u realizaciji ove ideje prvotno je 2014. godine prihvatila Nacionalna i sveučilišna knjižnica (NSK), prijavivši projekt naziva Suradnički sustav Hrvatske digitalne knjižnice na javni natječaj Ministarstva kulture RH, s vizionarskom idejom izrade pilot-projekta hrvatske digitalne knjižnice s građom iz repozitorija NSK, Knjižnica grada Zagreba (KGZ) i Knjižnice Hrvatske akademije znanosti i umjetnosti (HAZU), no Ministarstvo nije prepoznalo potrebu i potencijal takva projekta. Sljedeće su godine iste ustanove pokušale osigurati financijska sredstva s ponešto drugačijim pristupom, predloživši (ponovno neuspješno) »pilot-projekt razvoja tematskog agregacijskog sustava po uzoru na Europeanu, u kojem će se okupljati metapodaci o digitaliziranoj građi« (Juričić 2017b: 24).

\section{Projekt Znameniti i zaslužni Hrvati}

Ne odustajući u svom naumu realizacije suradničkih projekta, od nacionalne važnosti, Vedrana Juričić, ravnateljica Knjižnice HAZU, prijavila je 2016. na natječaj Zaklade Adris prijedlog pilot-projekta izrade tematskoga portala o znamenitim osobama pod nazivom Znameniti i zaslužni Hrvati, u »čijem je središtu te godine bio Ivan Kukuljević Sakcinski i njegova dvjestota obljetnica rođenja«. ${ }^{4}$ Ustanove okupljene u ovom projektu - HAZU, NSK, KGZ i Državni arhiv u Varaždinu (DAVŽ) - tada su već posjedovale digitalizirane zapise vezane uz Kukuljevića, kao i digitaliziranu građu o drugim znamenitim osobama, a aneksna je prednost bila činjenica da su njihovi institucijski digitalni repozitoriji bili postavljeni na identičnoj programskoj platformi ArhivX, odnosno njegovoj novijoj inačici Indigo koju je izgradila tvrtka ArhivPRO. Projektu su se naknadno priključile i druge ustanove koje posjeduju građu znanstvenika, umjetnika, književnika i drugih javnih osoba: Leksikografski zavod Miroslav Krleža (LZMK), Muzej za umjetnost i obrt (MUO), Institut za etnologiju i folkloristiku (IEF) i Centar za ženske studije (CŽS) (Juričić 2017b: 24), a naposljetku 2018. godine i udruga ICARUS Hrvatska, koja okuplja baštinske i informacijske stručnjake koji se bave dostupnošću povijesnih izvora kroz nove tehnologije i aktivnostima koje razvijaju i promiču međuinstitucionalnu i međunarodnu suradnju. klade Adris.

4 Juričić, Vedrana (2016). Prijedlog projekta »Znameniti i zaslužni Hrvati«. Favni natječaj Za- 
Naziv, kao i sam idejni koncept projekta inspirirani su leksikonom Znameniti i zaslužni Hrvati te pomena vrijedna lica u hrvatskoj povijesti od 925-1925. objavljenom 1925. godine. ${ }^{5} \mathrm{No}$, na samom se početku projekta pokazalo vrlo važnim jasno definirati što se podrazumijeva pod terminom »znameniti i zaslužni Hrvati«, kako bi se izbjegle potencijalne rasprave i nedoumice koje su se dale već naslutiti. Dakle, »riječ je o osobama koje su radile u Hrvatskoj ili izvan Hrvatske, bez obzira na podrijetlo ili rođenje, ili osobe koje su svojim djelovanjem pridonijele prepoznavanju, definiranju i afirmaciji hrvatskog identiteta i čiji su radovi postali važan dio hrvatske baštine« (Crnković i sur. 2017: 182). Potencijalnu rodno/spolno orijentiranu polemiku koju bi u suvremenom društvenom kontekstu mogao izazvati naziv Hrvati, kod onih koji tu riječ ne bi doživjeli kao imenicu koja se odnosi na Hrvate kao narod i koja nije zapravo rodno/spolno determinirana, nastojalo se izbjeći tako da je budućem portalu - pa time i daljnjem projektu - dodijeljen naziv Znameniti.hr.

Tijekom prvoga projektnog razdoblja bilo je dogovoreno da se »prvenstveno odabiru starije i ugledne ličnosti iz prošlosti, kako bi se izbjegla ograničenja zbog još uvijek važećih autorskih prava, (...) da se odabiru osobe koje u tekućoj godini imaju značajne obljetnice, te bez obzira na obljetnički karakter, osobe čija su djela digitalizirana u većem obimu i naposljetku (...) da se posebna pažnja posveti uključivanju znamenitih žena« (Juričić, 2017b: 24). Suradnici LZMK u tu su svrhu priredili računalne tablice s popisom znamenitih osoba iz svojih baza podataka, uz poveznice $\mathrm{s}$ prigodnim obljetnicama, koje su zamišljene kao predložak partnerima na projektu u pripremi materijala za nadolazeće objave i predstavljanje javnosti »novih« velikana.

Osnovna je zamisao projekta bila »omogućiti bolju dostupnost i korištenje nekomercijalnih znanstvenih, kulturnih i umjetničkih digitalnih sadržaja istraživačima i široj javnosti« (Crnković i sur. 2017: 182). Uspostavom jedinstvenoga portala koji objedinjuje zapise i građu o »prvacima hrvatske kulture, znanosti, umjetnosti i javnog života« (isto), omogućeno je jednostavno pretraživanje i pristup građi različitih hrvatskih kulturnih, umjetničkih i znanstvenih ustanova (više o procesu nastanka portala i kriterijima odabira zapisa, vidi Crnković i sur. 2017).

\section{Portal Znameniti.hr}

Portal Znameniti.hr zaživio je u rujnu 2017. godine, na domeni http://znameniti.hr, koju su besplatno i na trajno korištenje dodijelili Ministarstvo kulture RH i CARNet (Juričić 2017b: 24), a uredništvo portala čini po jedna odgovorna osoba iz svake od partnerskih institucija. Portal omogućuje jedinstveni pristup metapodatcima (i gra-

5 Znameniti $i$ zaslužni Hrvati te pomena vrijedna lica u hrvatskoj povijesti od 925-1925. Odbor za izdavanje knjige Zaslužni i znameniti hrvati 925-1925., Zagreb 1925. (pretisak: Zagreb: »August Cesarec«, Ljubljana: Delo, 1990). 
đi) prikupljenima iz digitalnih repozitorija različitih kulturnih i znanstvenih ustanova koji su vezani »uz znamenite i zaslužne Hrvate iz svih područja znanosti, umjetnosti i života uopće« (Juričić, 2017b: 24-25). Uz to, portal sadržava i poveznice prema biobibliografskim podatcima iz Hrvatske enciklopedije i drugih izdanja LZMK te poveznice prema međunarodnoj bazi standardnoga identifikatora imena (ISNI) (Juričić 2017b: 25). Na kraju prve godine trajanja projekta na portalu je bilo zastupljeno trideset i pet osoba s ukupno 6511 zapisa, ${ }^{6}$ što je koordinatorica projekta V. Juričić prepoznala u jednom od svojih osvrta kao »znakovit nerazmjer između ugleda i važnosti neke osobe naspram njezine zastupljenosti u digitalnim izvorima naših kulturnih i znanstvenih ustanova« (Juričić 2017b: 25). Isto tako, početni plan o dinamici objavljivanja, odnosno izboru osoba koje će se predstavljati na portalu pojedine godine temeljen na prigodnim obljetnicama, pokazao se teško ostvarivim u praksi.

U planu za 2018. godinu bilo je uvrštavanje Marina Držića, Julija Klovića, Emilija Laszowskog, Ladislava Šabana, Augusta Šenoe, Antuna Branka Šimića i drugih, dok primjerice uvrštavanje djela Marina Getaldića, čime je trebalo obilježiti njegovu »450. godišnjicu rođenja, nije bilo moguće budući da ni jedna od suradnih ustanova nije do sada digitalizirala građu vezanu uz našeg znamenitog matematičara« (Juričić 2017b: 25). Takvi slučajevi zapravo samo upućuju na činjenicu da dosadašnja digitalizacija $u$ većini ustanova nije bila pomno planirana u odnosu na kulturnu baštinu u cjelini niti sustavna, što nije nužno i kritika samih ustanova i njihovih politika. Naime, zbog nedostatka stručnoga kadra koji bi se bavio poslovima digitalizacije i nedostatka financijskih sredstava većinom se digitalizirala građa vezana uz pojedine tekuće projekte, zahtjeve vanjskih korisnika ili redovne aktivnosti. Iz tih su razloga dostupni digitalizirani sadržaji zapravo nasumičan izbor građe određene ustanove, a ne pokazatelj stvarnoga fundusa ili značenja osobe čija se građa prebacila u digitalni oblik, u kojem slučaju ovaj portal može »poslužiti i kao praktičan alat za pronalaženje 'crnih rupa' u sadržaju naših digitalnih repozitorija« (Juričić 2017b: 25).

6 Vedrana Juričić navela ih je »redoslijedom na čijem su čelu oni koji su najzastupljeniji po broju zapisa: Adam Mandrović, Nikola Faller, Ivan Kukuljević Sakcinski, Antun Gustav Matoš, Vinko Žganec, Tomislav Krizman, Tošo Dabac, Nikola Andrić, Menci Klement Crnčić, Dimitrije Demeter, Ivan Meštrović, Ivo Vojnović, Milan Ogrizović, Šime Ljubić, Frano Kršinić, Ruđer Bošković, Milan Begović, Ljudevit Gaj, Vatroslav Lisinski, Milan Rešetar, Viktor Kovačić, Janko Ibler, Antun Motika, Julije Benešić, Celestin Medović, Dragutin Tadijanović, Andrija Mohorovičić, Lavoslav Ružička, Ivan Zajc, Rudolf Valdec, Ivana Brlić-Mažuranić, Neven Šegvić, Petar Preradović, Josip Jelačić« (Juričić 2017b: 25). 

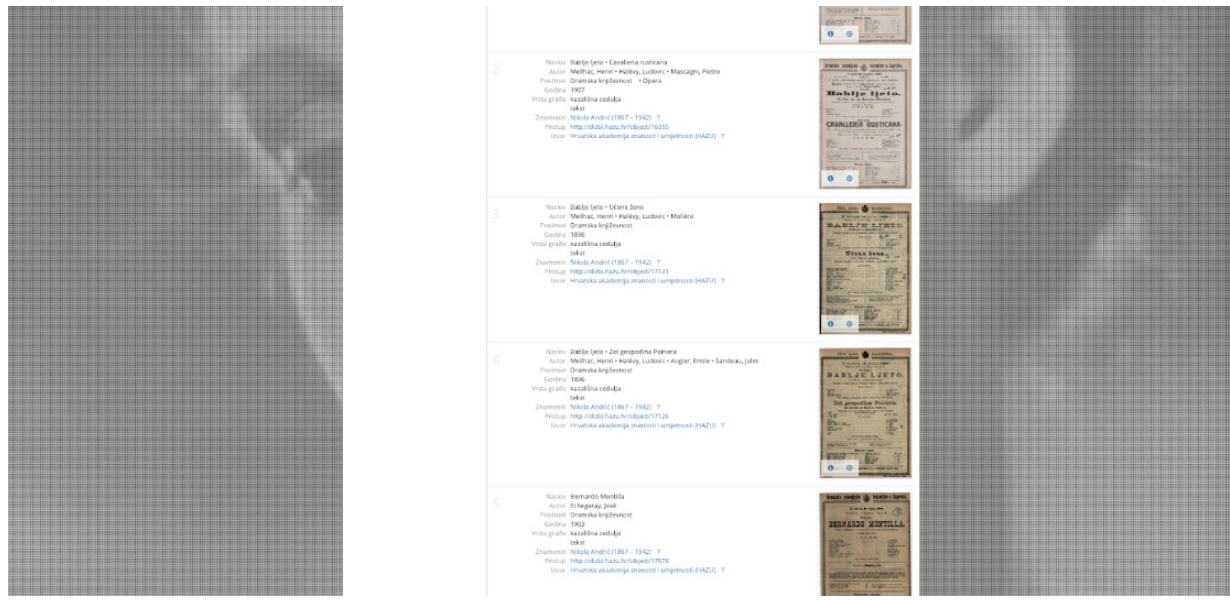

Portal Znameniti.hr - sučelje za pregled zapisa

Službenim završetkom projekta Znameniti i zaslužni Hrvati u svibnju 2017. godine zaključeno je i samo financiranje portala, što je dovelo u pitanje potencijalno gašenje i/ili dovođenje projekta u status quo. Takva je situacija suradnike na projektu potaknula na osmišljavanje novoga modela suradnje koji bi osigurao održivost i daljnji razvoj portala. Potpisivanjem Sporazuma o suradnji između partnerskih ustanova (uključujući arhive, knjižnice, muzeje, istraživačke institucije, kao i tvrtke koje se bave informacijskim tehnologijama) suradnici su se obvezali nastaviti rad na projektu, neovisno o vanjskom financiranju. Tako je dogovoreno da će Sveučilišni računski centar (Srce) kao svoj in-kind ${ }^{7}$ doprinos DARIAH-HR konzorciju ${ }^{8}$ osigurati serversku podršku, odnosno dovoljno mjesta za pohranu digitalne građe u oblaku. Druge partnerske ustanove ugovorom su se obvezale da će (po potrebi) svake godine druga institucija preuzimati koordinaciju, a rast i obogaćivanje platforme novim sadržajem osigurati svojim in-kind doprinosima. Iznimno važan i uzajamno koristan dio međusobnoga dogovora jest taj da svaka nova funkcionalnost platforme razvijena u okviru bilo kojega pojedinačnoga projekta postane dostupna za upotrebu svim partnerima i korisnicima platforme Indigo, čime se izbjegava višestruko plaćanje za iste module i funkcionalnosti. ${ }^{9}$ Tako se trudom, solidarnošću i međusobnim poticajima partner-

$7 \quad$ In-kind se odnosi na onu vrstu doprinosa nekoga pojedinca ili ustanove koji nisu novčani, već iskazani, primjerice, u vidu usluga, alata, uloženoga vremena i materijala.

8 Hrvatski nacionalni ogranak DARIAH-ERIC-a čiji je koordinator Institut za etnologiju i folkloristiku, a koji obuhvaća u ovome trenutku trideset i tri institucije u Hrvatskoj te, kao središte tzv. Western Balkan Huba, šest institucija u Bosni i Hercegovini i Makedoniji.

9 Kuzman Šlogar, Koraljka (2018). Prijedlog projekta »Eminent People: A Model of Sustainable European Platform for Digital Research«, DARIAH THEME 2018/2019 Strategic Service Sustainability for DARIAH. DARIAH-HR arhiva. 
skih institucija omogućuje daljnji razvoj portala. Sredstva za digitalizaciju i objavu nove građe osiguravaju se dvojako, ne samo kroz suradničke, već i u okviru samostalnih projekata.

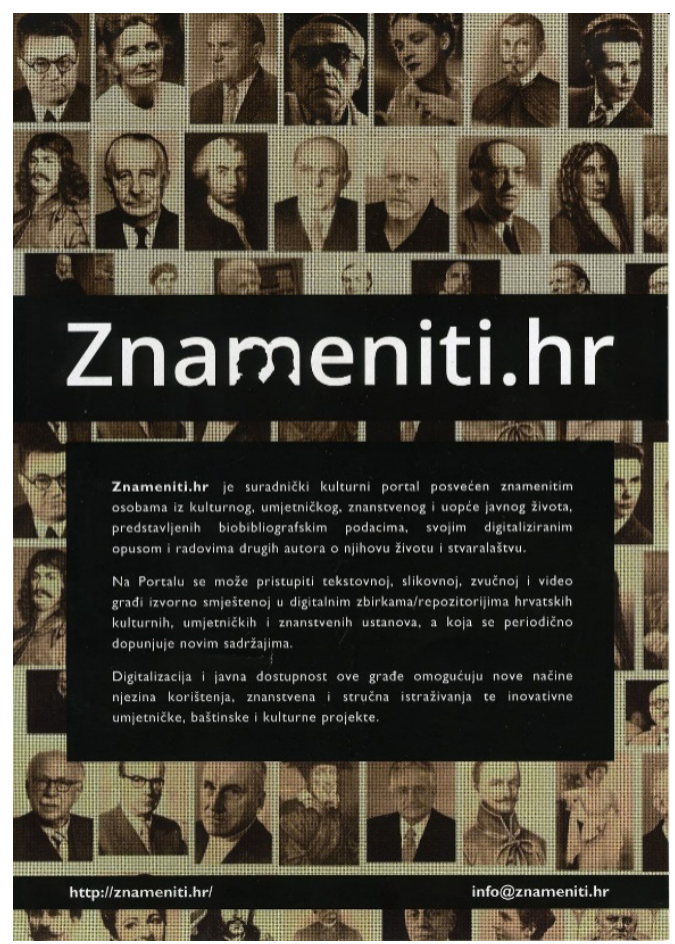

Promotivni letak za Znameniti.hr tiskan početkom 2019.

Kroz takve je samostalne institucijske projekte za objavu na suradničkom portalu tijekom 2018. i 2019. godine digitalizirana i pripremljena znatna količina građe, odnosno predstavljeni su mnogobrojni »novi« znameniti. Tako je, primjerice, IEF povećao broj objavljenih zapisa vezanih uz rad i postignuća dvoje akademika, Vinka Žganca i Maje Bošković-Stulli, te prezentirao radove Toše Dapca. KGZ je portal obogatio sadržajem koji predstavlja Mariju Jurić Zagorku, Augusta Šenou i Ivana Kukuljevića Sakcinskog, a ICARUS Hrvatska je kroz svoj digitalni repozitorij, koji je namijenjen objavi građe zainteresiranih ustanova koje nemaju istovrsnu programsku podlogu na portal, dodao arhivsku građu Sveučilišta u Zagrebu i Državnoga arhiva u Bjelovaru o već predstavljenima osobama (Ivan Kukuljević Sakcinski, Petar Preradović i dr.). Ideja je kreatora ovoga portala da Znameniti.hr bude početak »male hrvatske Europeane . $^{10}$ Širenjem baze suradnih ustanova koje svoju digitaliziranu

10 »Europeana, najveća digitalna platforma u Europi, razvija se već deset godina na principima i standardima koji su povezani i primjenjuju se na portalu Znameniti.hr« (Crnković i sur. 2017: 182). 
građu mogu objaviti na portalu neovisno o svojim tehničkim i organizacijskim mogućnostima, što je omogućeno uključivanjem ICARUS-a Hrvatska u projekt kao partnera koji će koordinati ovu aktivnost, otvorilo je portalu Znameniti.hr nove mogućnosti širenja svojega djelovanja kao suradničke platforme i osnažilo mu važnost nacionalnoga projekta. Digitalni repozitorij ICARUS Hrvatska ustanovljen je za sve baštinske institucije koje nemaju vlastite digitalne repozitorije te će ovdje moći pohranjivati i digitalnu građu i metapodatkovne opise u svrhu njihova agregiranja na tematski portal Znameniti.hr.

\section{Projekt Znamenite žene i tekuće aktivnosti}

U prvoj fazi projekta, »čast izbora objave na portalu pripala je onim osobama koje su u 2017. obilježile značajne obljetnice rođenja ili smrti o kojima je do sada prikupljena opsežnija zbirka digitaliziranih objekata koji se bez autorskopravnih ograničenja mogu objaviti na internetu«. Prema navedenim kriterijima tada je, kao što je već spomenuto, »na portalu objavljena građa koja se odnosi na 35 znamenitih osoba odnosno sveukupno 6.406 zapisa s metapodacima«.11 Među njima se, međutim, nalazila samo jedna žena - Ivana Brlić-Mažuranić. Kako bi ispravili tu činjenicu, suradnici su pripremili idući projektni prijedlog s ciljem postizanja ravnomjernije spolne zastupljenosti na portalu, koji su i ostvarili zahvaljujući sredstvima osiguranima putem prijave na javni natječaj Ministarstva kulture RH za 2018. za projekt posvećen digitalizaciji građe o znamenitim Hrvaticama.

U prijavnom je obrascu obrazloženo kako se u dotadašnje planove digitalizacije žene nisu često uvrštavale - kao autorice i javne osobe - jer su dominantne, društveno važne i česte teme bile zapravo one u kojima su dominirali autori muškarci te su nevelika raspoloživa sredstva za digitalizaciju uglavnom bila i usmjerena na njih. Nadalje, »u patrijarhalnom društvu, kakvo je bilo dugo na ovim prostorima, žene su bile u drugom planu, i nisu se ravnopravno angažirale u znanosti, umjetnosti, javnom djelovanju. Tako da je i njihovih radova manje«. To su bili razlozi predlaganja projekta koji bi bio posvećen isključivo »znamenitim autoricama koje su obilježile hrvatsku kulturu, umjetnost i znanost«, a kako bi se mogle u »zadovoljavajućoj mjeri nadoknaditi razlike koje se trenutno zamjećuju na portalu«. ${ }^{12}$ Znamenite $\mathrm{Hr}$ vatice čije je nasljeđe digitalizirano i predstavljeno u okviru ovoga projekta bile su, primjerice, doajenke hrvatske etnologije Maja Bošković-Stulli i Dunja Rihtman-Auguštin, književnice Ivana Brlić-Mažuranić i Marija Jurić Zagorka, Antonija Kas-

11 Juričić, Vedrana (2017d). Prijedlog projekta »Digitalizacija građe o znamenitim Hrvaticama«. favni natječaj Ministarstva kulture 2017.

12 Isto. 
sowitz-Cvijić, Marija Jambrišak, Anica Bošković, Elly Ebenspanger, Jagoda Brlić i druge.

Po završetku ovoga projekta, tijekom 2018. i 2019. godine prijavljen je, više ili manje uspješno, još niz manjih projekata na različite javne natječaje i pozive kroz koje su projektni partneri nastojali osigurati sredstva za širenje baze suradnika, popularizaciju portala, razvoj publike te dodavanje novih digitaliziranih sadržaja i nadogradnju novih funkcionalnosti. Jedan od onih koji nije dobio potporu bio je prijedlog projekta Digitalizacije građe o znamenitim obiteliima prijavljen na javni poziv za predlaganja programa javnih potreba u kulturi za 2019. za digitalizaciju arhivske, knjižnične i muzejske građe kojim se predlagalo »objaviti građu o članovima obitelji do sada predstavljenih osoba i podatke o znamenitim hrvatskim obiteljima koje su obilježile hrvatsku kulturu, umjetnost i znanost, kao što su Zrinski, Radić, Mažuranić, Deželić, Vojnović, Stulli i dr. kako bi portal proširili novim sadržajima«. ${ }^{13} \mathrm{No}$, na istom su natječaju LZMK i NSK zasebnom prijavom osigurali sredstva za provedbu projekta Digitalna zbirka Mate Ujevića, a IEF za projekt Hrvatska kulturna baština u crtežima Živka Kljakovića, tako da će portal biti obogaćen novim sadržajima vezanima uz te dvije znamenite osobe.

ICARUS Hrvatska je u suradnji s partnerima također pripremio prijedloge projekata na više nacionalnih javnih poziva za 2019. godinu: za programe koji potiču razvoj publike u kulturi u Republici Hrvatskoj za Znameniti.hr izbliza i Predstavljamo Znamenite, za potporu programima popularizacije znanosti Znanstvenici na mreži te lokalne natječaje za potporu programima na području kulture i baštine kao što su Znameniti Vinkovčani i Znameniti Varaždinci prijavljene u tim gradovima, uz više prijava poslanih na otvorene natječaje za sponzorstva i donacije koje provode gospodarski subjekti i javne institucije. Posebno mjesto u tekućim aktivnostima ima projekt Povijesni izvori vojvođanskih Hrvata na Internetu koji je dobio podršku Ureda za Hrvate izvan RH za 2019. i koji ICARUS Hrvatska provodi u suradnji sa Zavodom za kulturu vojvođanskih Hrvata iz Subotice te kroz koji će se na portal Znameniti.hr dodati gradivo znamenitih osoba kao što su Emerik Pavić, Josip Andrić i Grgur Čevapović, čija se građa čuva i u Hrvatskoj i izvan nje. Ovakve nove suradnje, uz već spomenuto otvaranje prostora za širenje mreže suradnika na portalu kroz »agregatorski« digitalni repozitorij ICARUS Hrvatska, Znameniti.hr ističe kao primjer »poticanja koordiniranog djelovanja, stvaranja sinergije nacionalnih napora, osnaživanja trendova povezivanja i umrežavanja sadržaja i ujedinjena kompatibilnih nacionalnih komponenti«, što su vrijednosti podržane u Nacionalnom planu digitalizacije kulturne baštine 2025 (Nacionalni plan digitalizacije kulturne baštine 2025: 2).

${ }_{13}$ Lemić, Vlatka (2018). Prijedlog projekta »Digitalizacija građe o znamenitim obiteljima«, favni natječaj Ministarstva kulture 2018. 


\section{EminentPeople: regionalna perspektiva}

Znameniti ljudi i informacije o njima nerijetko prelaze granice, tako da se podatci i građa koji se odnose na njih mogu naći u drugim zemljama, napose u onim susjednim. Stoga je bilo i logično, pri promišljanju daljnjih koraka u razvoju portala, usmjeriti djelovanja i u smjeru širenja suradnje na susjedne zemlje. Konzorcij DARIAH-ERIC je, otprilike u vrijeme završetka projekta Znameniti i zaslužni Hrvati, objavio javni poziv DARIAH Theme 2017: »Cultural Heritage and Humanities Research« za financiranje projekata iz područja digitalne humanistike i infrastrukture te se tako savršeno poklopio s potrebama i namjerama partnera okupljenih oko Znameniti.hr. U propozicijama natječaja jedan od traženih uvjeta bio je uključivanje suradnika najmanje jedne ustanove iz zemlje članice te jedne iz države koja nije članica DARIAH-a, što nas je usmjerilo prema Bosni i Hercegovini i Sloveniji. Na suradnju je pozvano nekoliko novih partnerskih institucija: Slovenska akademija znanosti i umjetnosti te Zemaljski muzej Bosne i Hercegovine i Nacionalna i sveučilišna biblioteka Bosne i Hercegovine. Izbor je bio logičan s obzirom na postojanje ranijih kontakata i prethodnih suradnji s tim ustanovama, a napose s obzirom na činjenicu da zbog srodnih jezika neće biti većih jezičnih prepreka prilikom suradnje i korištenja portala (projektna sredstva nisu bila dovoljna za izradu višejezičnoga portala).

Prijedlog novoga projekta, uz suglasnost i potporu ostalih partnera, prijavila je ponovo ravnateljica Knjižnice HAZU Vedrana Juričić, a njime je predviđeno »povezivanje ustanova organizacijom zajedničkih radionica na kojima bi se raspravila bitna pitanja iz domene korištenja digitalne infrastrukture u kulturnim i znanstvenim zajednicama šire regije (Hrvatska, BiH i Slovenija) « (Juričić 2017a: 9-10). Fokus je bio na razmatranjima i testiranju mogućnosti povezivanja građe o znamenitim i zaslužnim pojedincima iz triju država, uključujući »pitanje interoperabilnosti repozitorija tj. mogućnosti povezivanja metapodataka i uspostave jedinstvenoga pristupa pretraživanju «, s osobitim naglaskom na problematiku autorskih prava, dakle »mogućnosti objave, korištenja i preuzimanja građe u digitalnom repozitoriju« (Juričić 2017a: 10).

Zahvaljujući uspješnoj prijavi, nacionalni pilot-projekt dobio je svoju nadogradnju u vidu novouspostavljenoga portala EminentPeople.eu kroz projekt naslova Okviri suradnje digitalnih infrastruktura u regiji - mogućnosti i potrebe na primjeru građe o znamenitim ličnostima znanosti i kulture (Cooperation Framework of Digital Infrastructure in the Region - Opportunities and Needs in Case of Material Concerning Famous People in Science and Culture). ${ }^{14}$ Tijekom godine dana, koliko je trajao projekt, održane su četiri radionice u Zagrebu na kojima su se okupljali isključivo

14 Više o projektu vidi: Papaki, Eliza (2019). Cooperation Framework of Digital Infrastructure in the Region of Croatia, Slovenia, Bosnia and Herzegovina, DARIAH News, June 14, 2019; https://www. 
suradnici na projektu. Na prvoj dvodnevnoj radionici (28-29. XI. 2017) određene su metode suradnje između znanstvenih i kulturnih institucija koje sudjeluju u projektu. Središnja problematika druge radionice (12-14. II. 2018), uz već pokrenutu prvu inačicu tematskoga portala EminentPeople.eu, bila su etička pitanja te autorska i srodna prava i preporuke. Na trećoj radionici (10-11. IV. 2018) testirala se prva verzija tematskoga portala, ispitivanjem profila metapodataka za pojedine vrste građe u različitim institucijama te isprobavanjem unosa metapodataka uz korištenje normativne baze NSK u Zagrebu za osobe, korporativna tijela i subjekte, a na kraju je odabran i popis osoba koji će se objaviti na tematskom portalu do kraja projekta. $\mathrm{Na}$ četvrtoj i posljednjoj u nizu radionica (2-3. VII. 2018) raspravljalo se, među ostalim, o dizajnu i formatu portala, njegovu uredništvu i drugim sitnim, ali vrlo važnim detaljima vezanima uz njegov konačan izgled i funkcionalnost. Pokazna verzija portala pokrenuta je u rujnu 2018. godine na adresi http://eminentpeople.eu (Juričić 2018).

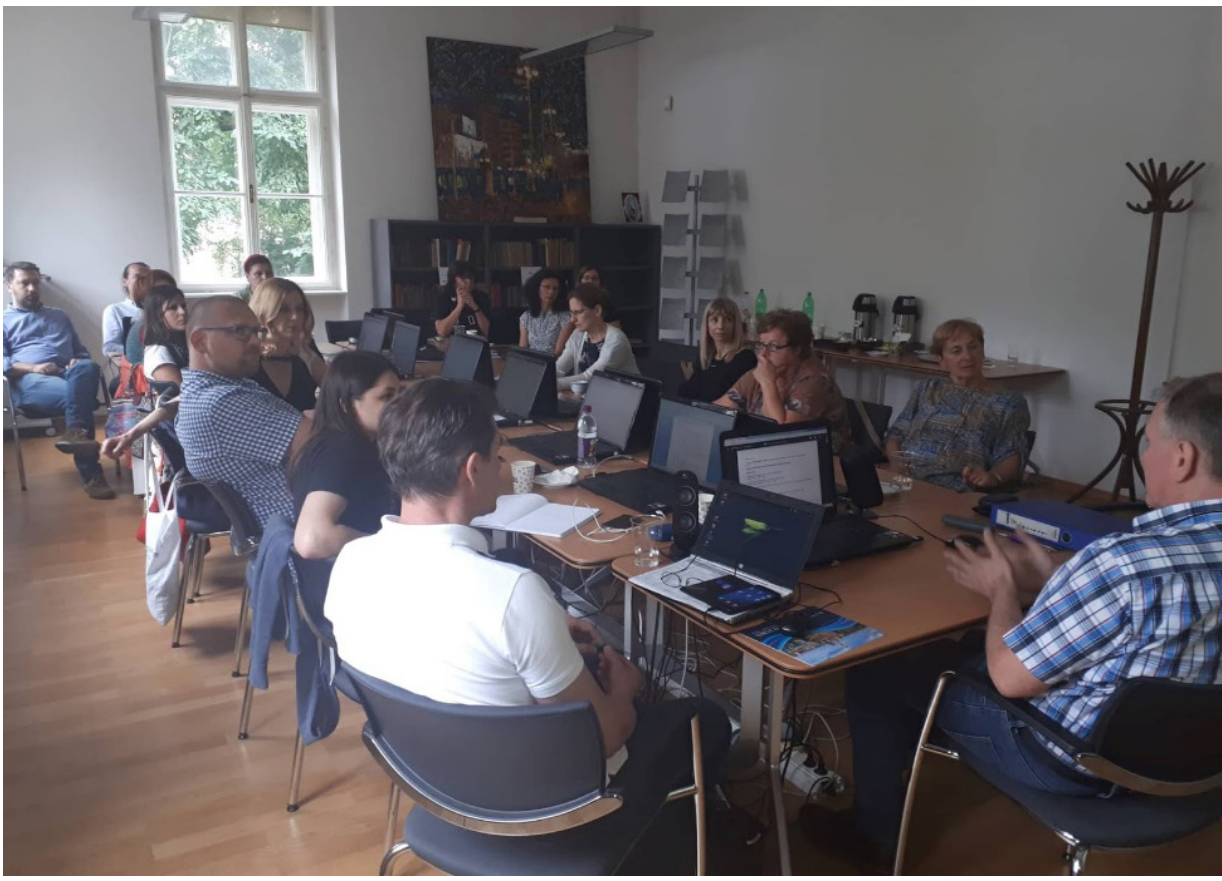

4. radionica u okviru CFDI projekta, Zagreb, 2. srpnja 2018.

Može se zaključiti kako je sam projekt nesumnjivo pridonio suradnji institucija znanosti i kulture u trima državama u domeni digitalne infrastrukture te potaknuo njezin razvoj i korištenje. Isto je tako omogućio učinkovitiju komunikaciju između

dariah.eu/2019/06/14/cooperation-framework-of-digital-infrastructure-in-the-region-of-croatia-slovenia-bosnia-and-herzegovina/ 
institucija u regiji, osiguravši sredstva za nalaženje partnera na projektu. Međutim, po završetku financiranoga projektnog razdoblja ovaj se portal, kao i organizirani nastavak suradnje, suočio s istim problemima kao i Znameniti.hr - s nedostatkom financijskih sredstava $i$ institucijske podrške kao presudnim čimbenicima održivosti svakoga projekta.

\section{Što i kako dalje? Europska perspektiva}

Raspršenost projekata, neriješena i otvorena pitanja održivosti njihovih rezultata po završetku razdoblja financiranja, slabe mogućnosti financiranja institucijskih repozitorija, nepostojanje nacionalnoga strateškog plana i infrastrukture kao odgovor aktualnim potrebama, ističu se kao najčešći problemi i znanstvene i AKM zajednice. Međunarodna udruženja i konzorciji koji se formiraju upravo radi umrežavanja, suradnje i rješavanja zajedničkih interesa i problema - poput DARIAH-a i ICARUS-a, do sada su se pokazali kao najpouzdaniji oslonac, bilo da se radi o nacionalnim problemima i/ili projektima bilo o međunarodnim programima i inicijativama. Na nacionalnoj se razni, na temelju dosadašnjega iskustva, pokazalo nemogućim osigurati adekvatnu potporu nadležnih državnih tijela, koja i dalje ne prepoznaju nužnost i korist od digitalizacije u sektorima znanosti i kulture (neovisno o javnoj promociji strategija i medijskim napisima o važnosti ulaganja u digitalizaciju društva - institucije i projekti o kojima je ovdje riječ nisu uočile praktične promjene koje bi slijedile takve najave). Jedini mogući put kojim ustanove mogu doći do financijskih sredstava $\mathrm{u}$ ove svrhe je putem prijava na relevantne javne natječaje, no dosadašnja je praksa pokazala da se odobrenim projektima u pravilu dodjeljuju znatno manja sredstva od traženih, što dovodi do nemogućnosti potpune provedbe planiranih aktivnosti.

Suočeni s tim činjenicama, a svjesni europskoga potencijala tematskih portala, suradnici su shvatili da je jedini način osiguranja razvoja i održivosti započetih projekta njihovo širenje preko granica države i regije. Namjera je u nadolazećim godinama razviti održivu paneuropsku platformu za transnacionalna digitalna istraživanja u području umjetnosti i humanističkih znanosti, na primjeru znamenitih osoba iz javnoga života čije je djelovanje samo po sebi nadnacionalno i posvećeno univerzalnim vrijednostima. Implementacijom višejezičnosti portal EminentPeople postao bi relevantan ne samo za područje zapadnoga Balkana već i za sve dijelove Europe (i svijeta) koji će se moći služiti njime. Cilj je unaprijediti softver postojeće programske platforme Indigo u verziju s višejezičnim sučeljem koja bi omogućavala pohranu multimedijske digitalizirane građe, usklađenu sa standardima i potrebama istraživačke i AKM zajednice, pripremljenu za međusobnu razmjenu materijala s Europeanom. Također, u planu je kreirati i implementirati na portalu različite module, poput onih za pripremu online izložbi ili za edukaciju, koji su važni za veću vidljivost i korištenje portala. Koncept ove platforme također će se moći koristiti i 
zasebno za svaku državu, prema njihovim potrebama i željama, kao što će se i u Hrvatskoj i dalje zadržati aktivna nacionalna verzija platforme na domeni Znameniti.hr te kontinuirano nastaviti s objavljivanjem novih materijala o znamenitim osobama. ${ }^{15}$

Tekuće aktivnosti i daljnji planovi partnerskih ustanova okupljenih oko projekta Znameniti.hr također su usmjerene na javnu promociju portala čime se želi objavljene kulturne sadržaje dovesti do što većega broja istraživača i korisnika te potaknuti širu publiku na upoznavanje s ustanovama u kojima se čuva kulturna baština (knjižnice, muzeji, arhivi, akademske institucije i dr.). Za potrebe razvoja publike i edukacije suradnici su izradili i razne promotivne materijale, a sam logo portala dizajnirala je Anja Tkalec iz Knjižnice HAZU. U javnim predstavljanjima, predavanjima i diseminaciji informacija o portalu podjednako sudjeluju sve suradne ustanove, sa zajedničkom misijom »stvaranja kritične mase lako dostupnih kulturnih sadržaja za ponovno korištenje u obrazovanju, umjetnosti, znanosti i gospodarstvu. Digitalizacija, mrežna dostupnost i dugoročno očuvanje digitalnih sadržaja jesu i bit će nužan preduvjet za pristup kulturnim sadržajima i znanju za sve, kao i za promociju nacionalne baštine, identiteta i raznolikosti u europskom okruženju« (Nacionalni plan digitalizacije kulturne baštine 2025: 3).

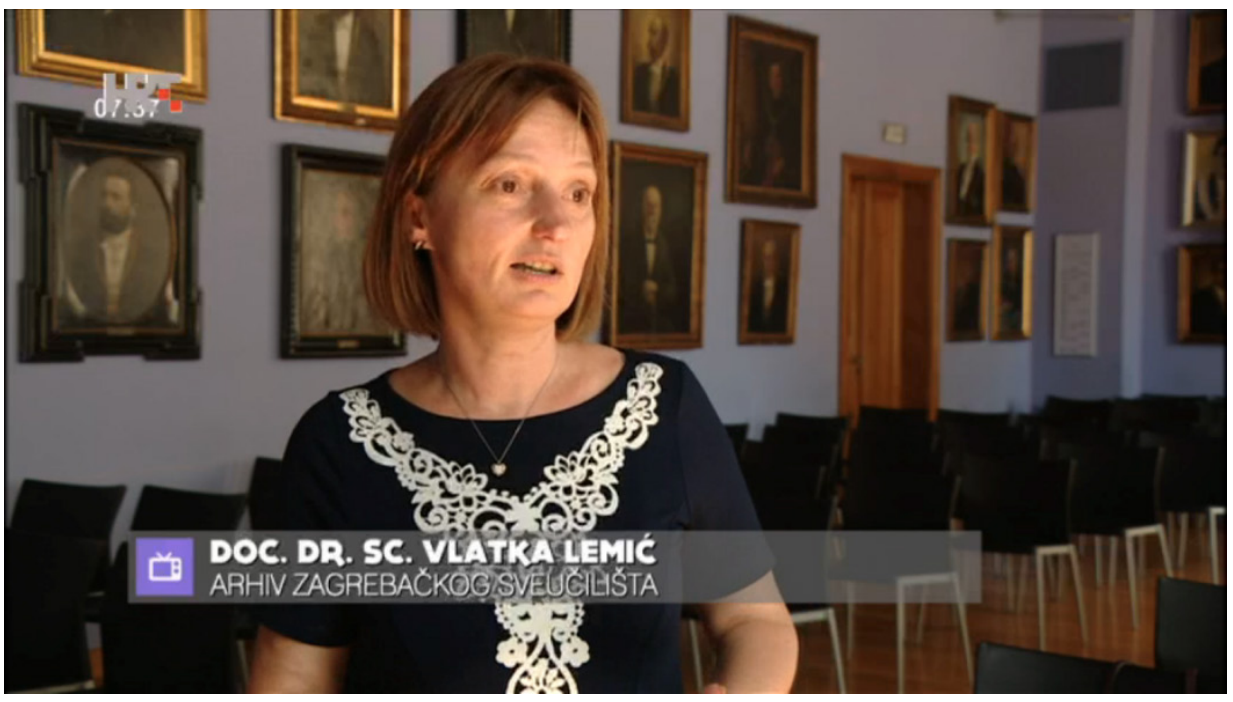

TV prilog Znameniti.hr nudi digitalizirana djela velikana hrvatske kulture, Magazin, HRT Autorica priloga: Ira Karlović/HRT, 24. srpnja 2019.

15 Kuzman Šlogar, Koralika (2018). Prijedlog projekta »Eminent People: A Model of Sustainable European Platform for Digital Research«, DARIAH THEME 2018/2019 Strategic Service Sustainability for DARIAH. DARIAH-HR arhiva. 


\section{LITERATURA I IZVORI}

Crnković, Kristijan, Juričić, Vedrana, Starčević Stančić, Irina (2017). »Thematic portal Znameniti. hr«, INFuture2017: Integrating ICT inSociety, 181-187. (http://infoz.ffzg.hr/INFuture/2017/conference-proceedings/infuture2017-proceedings).

ESFRI Roadmap (2006). European Strategy Forum on Research Infrastructures ESFRI. European Roadmap for Research Infrastructures Report 2006. (https://ec.europa.eu/research/infrastructures/pdf/ esfri/esfri_roadmap/roadmap_2006/esfri_roadmap_2006_en.pdf; pristupljeno 1. VIII. 2019).

EminentPeople (https://eminentpeople.eu/)

Juričić, Vedrana (2017a). Projekt »Okviri suradnje digitalnih infrastruktura u regiji - mogućnosti i potrebe na primjeru građe o znamenitim ličnostima znanosti i kulture«. @ rhivi 1(2), 9-10 (https:// hrcak.srce.hr/212968).

Juričić, Vedrana. (2017b). Tematski portal Znameniti.hr. @rhivi, 1 (2), 24-25 (https://hrcak.srce. $\mathrm{hr} / 212978)$.

Juričić, Vedrana (2018). Project »Report on Cooperation Framework of Digital Infrastructure in the Region - Opportunities and Needs in Case of Material Concerning Famous People in Science and Culture" (http://dariah.hr/arhivaDARIAH-CFDI_final-report_web.pdf)

Kuzman Šlogar, Koraljka (2017). »Izazovi digitalne transformacije humanistike i umjetnosti«, Hrvatski iseljenički zbornik, 2018., str. 40-52.

Lemić, Vlatka (2017). Digitalizacija u hrvatskim arhivima: stanje i perspektive, u: Ivan Fras (ur.), 16. Zbornik mednarodne konference Tehnični in vsebinski problemi klasičnega in elektronskoga arhiviranja, Radenci, 5.-7. april 2017. Maribor: Pokrajinski arhiv, str. 97-116 (http://www.pokarh-mb.si/ uploaded/datoteke/Radenci/radenci_2017/07_lemic_2017.pdf)

Nacionalni plan digitalizacije kulturne baštine 2025. (https:/esavjetovanja.gov.hr/ECon/ MainScreen?entityId=10350)

Znameniti.hr (http://znameniti.hr/)

Wiler, Mirna (2018). $O A K M-u$. Arhivi, knjižnice, muzeji (http://akm.hkdrustvo.hr/o-akm-u/; pristupljeno 1. VIII. 2019). 


\title{
THEMATIC PORTALS ZNAMENITI.HR AND EMINENTPEOPLE.EU - THE CHALLENGES AND PERSPECTIVES OF THE VIRTUAL NETWORKING OF DIGITAL REPOSITORIES
}

\author{
Vlatka Lemić \\ University of Zagreb \\ vlatka.lemic@unizg.hr \\ Koraljka Kuzman Šlogar \\ Institute of Ethnology and Folklore Research, Zagreb \\ koraljka@ief.hr
}

\begin{abstract}
Thanks to numerous innovative technologies and methods, the Information Age has brought new challenges, but also new opportunities, to the cultural and scientific sector, for both the development and the presentation of its primary activities. More importantly, it paved the way for new networking possibilities through inter-institutional and multidisciplinary collaborative projects, based on linking together analogous needs, efforts, and ideas. The goal of this paper is to present and examine the opportunities for cooperation in a virtual environment between related institutions, gathered around a common project involving the development of a collaborative portal about eminent and meritorious persons. We shall present the project through three basic phases of development: the inception of the idea and the launching of the national pilot project 'Znameniti i zaslužni Hrvati' (Eminent Croats) that resulted in the creation of the portal Znameniti.hr; the one-year European project funded by the DARIAH-ERIC consortium that enabled the establishment of regional cooperation and the creating of the portal EminentPeople.eu; and the preparation of a new international project considering the European perspectives of this portal.
\end{abstract}

Keywords: collaborative portal; institutional cooperation; digital repository; digitalisation; eminent persons; cultural and scientific heritage 